\title{
Baseline survey: Summary report of district Khanewal
}

Pakistan Initiative for Mothers and Newborns (PAIMAN)

Follow this and additional works at: https://knowledgecommons.popcouncil.org/departments_sbsr-rh

Part of the Family, Life Course, and Society Commons, and the Maternal and Child Health Commons How does access to this work benefit you? Let us know!

\section{Recommended Citation}

Pakistan Initiative for Mothers and Newborns (PAIMAN). 2006. "Baseline survey: Summary report of district Khanewal." Islamabad: Population Council. 


\section{Baseline Survey Summary Report}

District Khanewal

\section{Introduction}

This summary report presents some of the key findings of a 2005 baseline household survey in Khanewal district, one of the ten districts in Pakistan that are the focus of the PAIMAN project. The Pakistan Initiative for Mothers and Newborns (PAIMAN) is a five-year project funded by the United States Agency for International Development (USAID). PAIMAN is committed to assist the Government of Pakistan in its implementation of the full spectrum of interventions necessary to address maternal and neonatal health $(\mathrm{MNH})$ issues. The PAIMAN district survey results are presented individually; the districts are: Rawalpindi, Jhelum, Khanewal and DG Khan in Punjab; Dadu and Sukkur in Sindh; Jaffarabad and Lasbela in Balochistan; and Upper Dir and Buner in North West Frontier Province.

PAIMAN has developed a monitoring and evaluation plan to ensure that the success of the project is properly ascertained, and that the appropriate lessons learned. PAIMAN conducted the baseline household survey in the ten districts in order to understand local MNH perceptions and practices. The study population included all currently married women of reproductive age (15-49 years) living in all urban and rural areas of the district. The sampling design was a stratified, systematic sample of households.

In Khanewal, 851 women were interviewed, of whom 714 (84 percent) were rural. Thirty-four percent of respondents were literate. On average, respondents had borne 4.2 children, of whom 3.7 were still living. 


\section{Knowledge,}

Attitude

\section{and Behavior}

Figure 1: Percentage of married women in Khanewal who know at least 3 danger signs

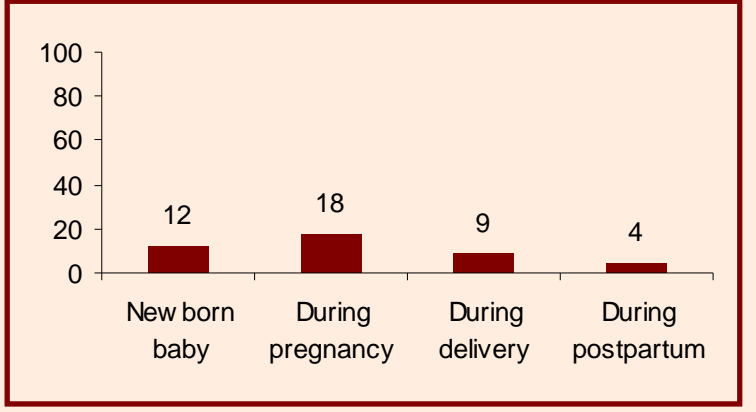

Figure 2: Percentage of married women in Khanewal who received antenatal care, TT injections and iron folate during their last pregnancy

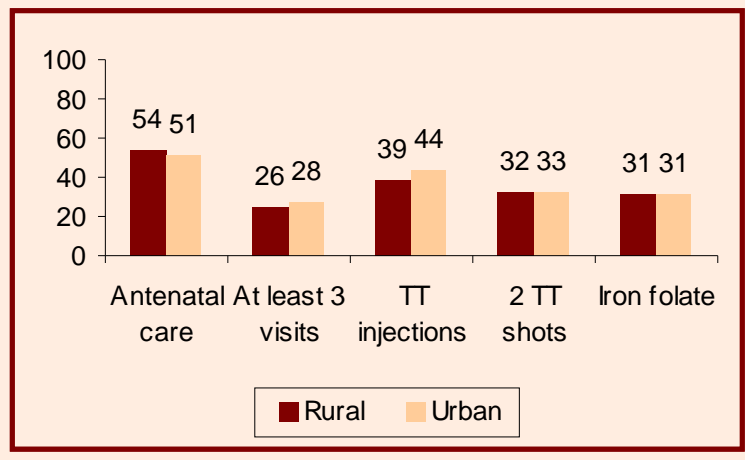

Figure 3: Percentage of married women in Khanewal who receive antenatal services during their antenatal visits, by type of services received

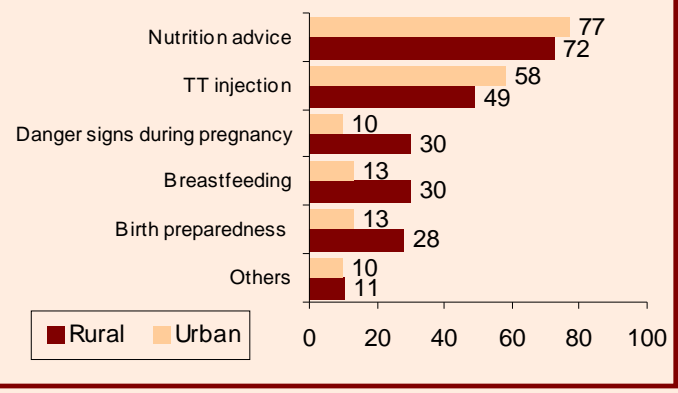

\section{Few Women Know Danger Signs Well}

\section{Knowledge of danger signs}

Only a small proportion of married women recognize three or more danger signs during pregnancy, during delivery, in the postpartum period, and in newborns (figure 1).

\section{Source of information regarding danger signs}

* Most receive information from their in-laws, family members and friends.

- About 16 percent in urban areas and 11 percent in rural areas indicate that they receive information primarily from television.

* Only 6 percent in rural areas indicate that Lady Health Workers are their source.

* Private hospitals and clinics are also a source for about 16 percent in urban areas and 8 percent in rural areas.

* For only 2 percent in urban areas and 3 percent in rural, District/ Tehsil Headquarter Hospitals are the source.

\section{Most Women Receive Antenatal Care}

* About 83 percent consider it necessary for women to receive antenatal check-ups.

* More than one-third believe that an antenatal check-up should occur in the first three months of pregnancy.

* For their last pregnancy, 54 percent of rural and 51 percent of urban women had at least one antenatal check-up but only 26 percent of rural and 28 percent of urban women had 3 or more, the national standard (figure 2).

* Nearly 44 percent in urban areas and 39 percent in rural areas had at least one TT injection during their last pregnancy, while 32 percent in rural and 33 percent in urban areas had 2 or more TT injections.

* Around 31 percent took iron folate tablets during their last pregnancy.

\section{Components of antenatal check-up}

Figure 3 suggests that most women are not advised about preparing for emergencies, although most received some advice regarding nutrition and immunization against tetanus.

\section{Many Women Prepare for Childbirth; Most Deliver at Home}

\section{Preparedness for childbirth}

Figure 4 shows that a large percent of women appear to have made appropriate arrangements for delivery.

Regarding possible emergencies, substantial proportions had made arrangements for money and transport, but a majority had not.

\section{Place of delivery and services}

* A majority ( 85 percent) agree that delivery services should be obtained from skilled birth attendants.

* Data obtained on the births that occurred during the last three years show that 74 percent of rural and 62 percent of urban women delivered their babies at home (figure 5).

* Thirty-three percent of deliveries were conducted by skilled birth attendant

\section{Delivery characteristics}

From figure 6, more than three-fourths of rural ( 80 percent) and 71 percent of urban respondents indicate they had a normal vaginal delivery. The proportion of 
Caesarean sections in rural and urban areas of Khanewal is almost the same (about 8 percent), and is within WHO guidelines (5 to 15 percent).

\section{Complications During Pregnancy and Childbirth are Common}

Nearly 54 percent of pregnant women in rural areas and 44 percent in urban areas indicate they experienced a complication during their last pregnancy. Severe abdominal pain, headache, prolonged vomiting and blurred vision are the complications most reported.

About 31 percent of women report experiencing at least one complication during delivery. The most commonly reported characteristics were excruciating abdominal pain, prolonged/obstructed labor, and premature rupture of membranes.

\section{Postpartum and Newborn Care Need Attention}

\section{Postpartum check-up}

- Both in rural and urban Khanewal, 43 percent of women feel that postpartum care is not necessary. Married women are often not aware of the complications that can arise following birth, and may ignore the symptoms.

- For those who delivered their last baby at home, almost 88 percent did not receive any postnatal check-ups.

* Among those who go for postnatal care, 15 percent go within 24 hours after childbirth.

\section{Immediate care of newborn}

- While nearly half of the mothers (45 percent) report that their newborns were with them immediately following delivery, a similar proportion indicate that their newborns are placed on either a piece of cloth or on a mattress.

* Almost 3 percent in rural areas indicate that their newborns are placed on the floor immediately after delivery.

- Overall in Khanewal 84 percent of the babies are given a bath within an hour of birth; only 11 percent are given one after the recommended six hours.

\section{Colostrum and breastfeeding}

Over 95 percent of urban and rural mothers indicate that they did breastfeed their child. In rural areas, 57 percent state that they gave colostrum to their babies; 76 percent did so in urban areas. Of those who gave colostrum to their newborn, 12 percent gave it within the first hour after birth. About 71 percent in rural areas and 81 percent in urban areas, report giving the baby something other than breast milk within the first 3 days.

\section{Neonatal care}

* For the last live child born, only about 20 percent were examined by a skilled provider

* The most common immediate signs/symptoms of complications noted by the mother were weak/no cry and difficult breathing. Diarrhea is the most commonly noted complication in newborns within the first seven days of their birth.

* Most common choices (41 percent in rural areas and 73 percent in urban areas) for children's treatment are private hospitals and clinics.

- No external treatment was sought for reported symptoms in 20 percent of rural cases.

\section{Clean Delivery Practices}

Respondents who delivered their last child at home report the following delivery practices:

- TBA did not wash her hands with soap for 7 percent of rural and 9 percent of urban deliveries.

- TBAs did not use a new blade for cutting the cord for over half of deliveries both in urban as well as rural areas. Scissors and knives were often used by TBAs.

- A new piece of thread was used for tying the cord for 86 percent of the deliveries.

Figure 4: Percentage of married women in Khanewal who made delivery arrangements, by type of arrangement

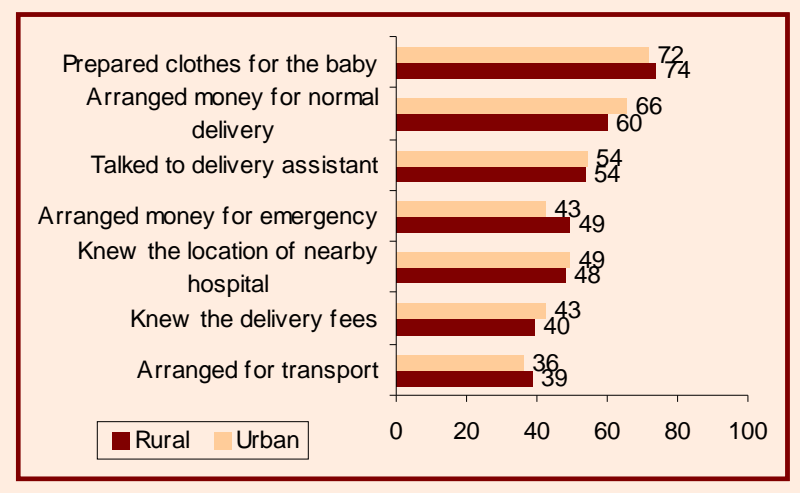

Figure 5: Percentage of married women in Khanewal who gave birth in the preceding three years, by place of delivery

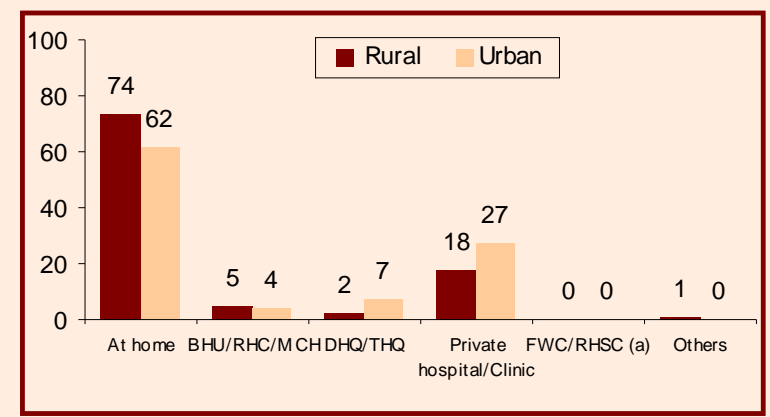

Figure 6: Percentage of married women in Khanewal who gave birth in the preceding three years, by type of last delivery

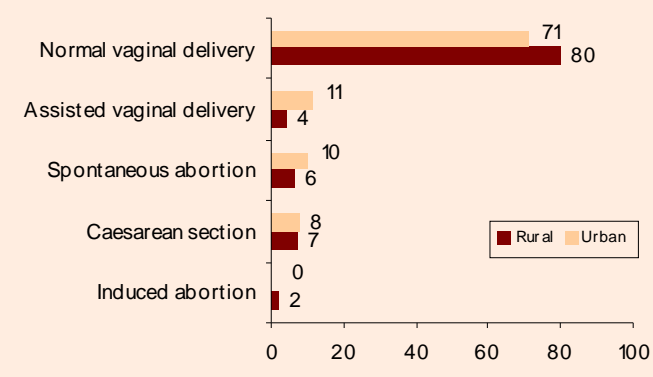




\section{Three Delays}

Delays in deciding to seek care, in reaching adequate health facilities, and in receiving appropriate care at health facilities lead to most maternal deaths.

\section{First delay: decisions must be made quickly}

* Women are prepared for delivery (figure 4) but don't know the danger signs well (figure 1), so are not well placed to make emergency decisions.

* Women rarely report themselves as most likely to make decisions for emergency delivery. Husbands (30 percent), family members ( 37 percent) or dais (27 percent) are more likely to make decisions for emergency delivery. Their preparedness to make such decisions is probably inadequate.

\section{Second delay: transport must be at hand and available}

* Of those who sought treatment for delivery complication, 61 percent used own transport or private transport to reach the health facility.

* The average waiting time for transport was 20 minutes.

* Transport averages 30 minutes to reach the desired facility, but in 9 percent of deliveries, it takes more than one

\section{Third delay: emergency services must be ready}

- After reaching the health facility, 94 percent report receiving services within 30 minutes. The median waiting time is 5 minutes.

- Appropriateness and quality of those services could not be ascertained.

\section{Access to media}

Half of the respondents in urban areas (figure 7) watch television, compared to 27 percent in rural areas. Few women listen to radio or read newspapers. About 58 percent of the population in urban Khanewal and 38 percent in rural Khanewal have access to some sort of media, whether television, radio or newspapers.

Figure 7: Percentage of married women in Khanewal who have access to mass media, by type of media

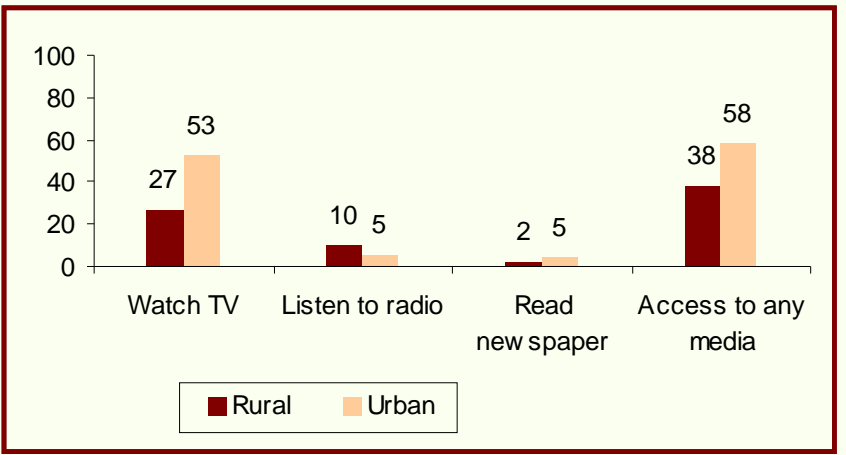

\section{Many pregnancies are unwanted}

* Twenty-five percent of respondents were using family planning at the time of the study. The most commonly used methods are female sterilization (10 percent), IUD (5 percent) and withdrawal (4 percent). More than one-fourth of respondents said they intended to use family planning in the future.

* Twenty-five percent of respondents said that their last pregnancy was either unwanted or mistimed. If unwanted pregnancies could be prevented in the first place, the attendant morbidity and mortality could be avoided.

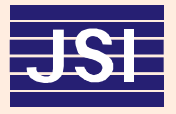

JSI Research \& Training Institute, Inc.

CA \# 391-A-00-05-01037-00 project is funded by the United States Agency for International Development

and implemented by JSI Research \& Training Institute, inc. in conjunction with Aga Khan University, Contech International,

Greenstar Social Marketing, Johns Hopkins University/CCP, PAVHNA, The Population Council, and Save the Children USA. 